\title{
E-Consumer Redress Mechanism for Negligence in Malaysia: A Survey Analysis
}

\author{
Jawahitha Sarabdeen \\ Faculty of Business \& Management, University of Wollongong in Dubai
}

\begin{abstract}
The law of contract cannot provide any remedies as parties concerned in most cases had no contractual relationship. A negligence tort is simply an accident that occurs when someone fails to pay attention and therefore, harms another person or thing. This research paper analyses the availability and the applicability of the negligence through survey. The issues like manufacturer's and service provider's liability and the difficulty of proving their liability will be analysed using the data collected through the survey. The finding shows that law of negligence in Malaysia has undergone very little development. The position of the e-consumers in Malaysia seems not satisfactory on the account of the fact that any contract term or notice purporting to exclude or restrict liability for the death and personal injury resulting from negligence may be effective and enforceable.
\end{abstract}

Keywords: Negligence, liability, e-consumer, ISP, redress

\section{Introduction}

E-consumers are increasingly involved in transactions where the purchaser and the vendor are located in different jurisdictions or countries. The web page may or may not carry information about the supplier and his place of business. Once the consumer has chosen the items of interest, he will proceed to the "cash register" where he will usually be asked to fill in a form and to make payment by credit card or electronic cash (Diane, 1997). By this, a transaction is concluded and the buyer has performed his duty and the seller's duty is yet to be performed. The problem will arise when the seller fails to deliver the goods on time or he fails to follow the description appeared on the Net or the seller refuses to deliver. What can the buyer do? Is there any remedy for him? When the goods sold over the Internet were not fit for the purpose for which they were sold, is it possible to bring an action against the seller?

Answers to the above and similar problems could not be found in the existing legislation. When a consumer decides to bring an action against a manufacturer or service provider for the injury or loss caused to him, the consumer will have no option but to resort to law of negligence since the law of contract cannot provide any remedies as parties concerned in most cases had no contractual relationship. A negligence tort is simply an accident that occurs when someone fails to pay attention and therefore, harms another person or thing. The tortfeasor neither wishes nor believes that his action will cause the damage but in fact, it caused harm or injury (Donoghue v. Stevenson, 1932). However, the negligence tort benefits the e-consumers when there is physical or property injury or death. It does not cover emotional injury. Even financial loss is covered only in limited cases. However, proving fault in the electronic environment on a specific defendant is extremely difficult as there are a number of parties ranging from manufacturer, service provider, ISP, portal site operators, search engines to Intranet operator. If he happens to prove fault, still he will not be able to recover any damages if the defendant is insolvent. Therefore, not only finding fault but also a solvent defendant is important to get some Copyright (C) 2010 Jawahitha Sarabdeen. This is an open access article distributed under the Creative Commons Attribution License unported 3.0, which permits unrestricted use, distribution, and reproduction in any medium, provided that original work is properly cited. The article is a reprint from a 2009 article. Contact author: Jawahitha Sarabdeen. E-mail: sarabdeenjawahitha@uowdubai.ac.ae 
compensation for the damage or injury done to the innocent e-consumer. Failure in finding solvent defendant will deprive the plaintiff from getting any compensation. This research paper analyses the availability and the applicability of the negligence through survey. The issues like manufacturer's and service provider's liability and the difficulty of proving their liability will be analysed using the data collected through the survey.

\section{Literature Review}

Generally a consumer who suffers injury due to mistake or negligence of manufactures or service providers will be able to bring a suit under negligence tort. This is because a person owes duty of care to anybody who is so closely and directly affected by the action or omission of another person. Therefore, the effect of this application is that a person is liable for every injury, which results from his carelessness (Keenan, 2000). This principle first established in the case of Donoghue v. Stevenson is called as neighbourhood principle. According to this principle, a person owes a duty of care to anybody who is so closely and directly affected by the action or omission of another person (Keenan, 2000). When the manufacturers' products harmed or injured the consumer or anybody who comes within the foreseeability range, then the consumers will be able to claim compensation for their suffering. The principle in this decision was later extended to others who ought to foresee that failure to take reasonable care might harm consumers regardless of whether the consumers were offline or online. This coverage may include retailers, repairers, those who hire out products, and those responsible for testing and certification of products (Scott \& Black, 2000).

If any of the victimized e-consumers would like to succeed in an action against a manufacturer or online service providers, the claimant must show the existence of duty of care which was owed to him by the defendant; breach of such duty; resulting damage to the consumer and the forseeability of the damage. It is important to note that all the elements often overlap and when the court decide a case, the court does not always regard them as separate matters.

The basic principle underlying the duty of care is that the people are expected to exercise a reasonable amount of care. In deciding whether a plaintiff had breached his duty, it is not necessary on the court to consider how a particular person would act. What is important is that the society's judgement on how an ordinary prudent person should act (Miller, \& Jentz, 2002).
Once the duty is established, the other element to prove negligent liability is to show breach of duty. Miller, L. R, and Jentz, A.G. say that normally the court considers the following factors in deciding that there is a breach of duty:

1. the likelihood that damage or injury will be incurred;

2. the seriousness of any damage or injury;

3. the cost and ease of taking precautions; and

4. social needs for the activities (Keenan \& Riches Sarah. 1998).

However, in case of breach of duty in designing products or goods, etc. the court generally will see:

1. whether the designer or producer knew or ought to have known of the likelihood of the product being used in a particular way;

2. was injury a reasonably foreseeable consequence? and

3. what if anything could be and should have done to avoid or reduce that risk? (Whincup, 1999).

Proving foreseeability and causation together with damage are important to succeed in an action in negligence (Vos, 2001). If the injury would not have occurred without the defendant's act, then the element of causation is missing because the connection between an act and injury is not strong enough to justify imposing liability (Miller \& Jentz, 2002).

In deciding the negligent liability the court needs to look at the question of who is most capable of taking effective precautions to prevent the damage. The persons who are most capable of taking effective precautions are most likely those on whom the courts will impose liability if they do not take such precautions. In the event of any damage caused by virus, it could be difficult to bring an action against service providers as they are not most capable person who can take effective precautions to prevent and also they may not be able to foresee the upcoming of new virus (Miller \& Jentz, 2002). However if an ISP is acting as publisher then the ISP is duty bound to provide adequate instructions, advice or warning if the publication contains inherent danger, and the reader by using or acting upon the information may cause injury or harm or death (Rich, 2006).

Under general law of negligence pure economic loss will not be compensated. Economic loss is either loss of profit or the reduction in value of an item of property. However in certain exceptional cases recovery will be possible. Thus Burgunder suggests that when the expert system is used for medical treatment and the system provides an inaccurate diagnosis or 
treatment that leads to detrimental medical complications, then it should be easy to prove that the expert system had a defect making it unreasonably dangerous (Burgunder, 2001). In addition, if a web site gives advice or information that is likely to be relied on by persons who come within the range of "special relationship", the website could be held liable. The possibility of being held liable in negligence is greater when the web site provides specific information (Stephenson, 2001). However, it is to be noted that the major problem on this tort in benefiting the e-consumers is that the consumer alleging negligence needs to show fault of the defendant. Proving fault in the electronic environment on a specific defendant is extremely difficult, as there are a number of parties ranging from manufacturer, service provider, ISP, portal site operators, search engines to Intranet operator involved. Even if he happens to prove fault, still he will not be able to recover any damages if the defendant is insolvent. Therefore, not only finding fault but also a solvent defendant is important to get some compensation for the damage or injury done to the innocent e-consumer.

\section{Methodology}

The methodology used in this paper is direct interview survey method. According to Malhotra, the main reason for conducting survey was to obtain insight and understanding of various issues in particular research topic (Malhotra, 2002). Since the current research sought to collect various opinions and insight of various qualified people open-ended structured interview schedule was used. In addition, survey method was used to avoid bias of the researcher unlike the method of observation. Among other survey methods direct interview had been chosen since it allows the highest flexibility of data collection. Because the respondents and the interviewer meet face to face, the interviewer can administer complex questions, explain, clarify and encourage a response to difficult questions. The directive interview method also gives the following advantages:

1. A wide variety of questions can be asked because the respondents can see the questions and an interviewer is present to clarify ambiguities, and

2. It gives effective and efficient sample control(Malhotra, 2002).

In constructing instrument items of the interview, an attempt was made to include questions only if they were needed to accomplish research objectives. Use of ambiguous words and double negative questions were avoided in order to enhance understandability of the respondents. The purpose and the nature of study were made known to the respondents. Each set of survey questions was accompanied with a covering letter, which was brief but focused on legitimacy of the researcher, request for co-operation, guarantee of anonymity and instruction about completing the survey.

The target population for the interview was planned to include the academicians of various higher learning institutions, practising lawyers, advisors of consumer organisations and other legal advisors whose minimum qualification was at least Bachelor's degree with a minimum of 2 years of working experience in the field of consumer and cyberlaw. The other criterion to fix the population was the persons with the working knowledge in cyber law and consumer law. Since there was no readily available directory in the area of consumer law and cyberlaw practitioners, the search process was carried out by browsing through the Internet to identify the individuals in different institutions, law firms, consumer organisations and companies. From that list 60 participants were identified as qualified to answer the questions in the survey. As the target population was 60 , the researcher decided to get the maximum response. The interview questions had been distributed to all the identified persons out of whom 32 only agreed to be interviewed. While collecting the responses, proper care was taken to give representations to all strata of identified groups namely academicians, lawyers, legal advisors. The following table gives the details about the representation of all strata.

\begin{tabular}{|c|c|c|c|}
\hline $\begin{array}{l}\text { Strata of } \\
\text { Population }\end{array}$ & 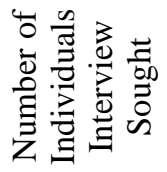 & 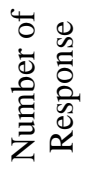 & 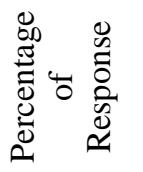 \\
\hline $\begin{array}{c}\text { Academici } \\
\text { ans }\end{array}$ & 25 & 18 & $56.25 \%$ \\
\hline $\begin{array}{c}\text { Practising } \\
\text { lawyers }\end{array}$ & 15 & 6 & $18.75 \%$ \\
\hline $\begin{array}{c}\text { Legal } \\
\text { advisors }\end{array}$ & 20 & 8 & $25 \%$ \\
\hline
\end{tabular}

The above table clearly explains that the participation was given to all. This may give the advantage of stratified random sampling. The 32 respondents represent $52 \%$ of the total response and it is considered as reasonable (Sample sizes larger than 30 and less than 500 are appropriate for most research. Uma Sekaran. 2003). Collected samples were carefully read and their responses were coded as follows.

1. Those who agreed with a particular question the answer were numbered as 4 . 
2. Those who said in between like "may be" or "perhaps" were numbered as 3.

3. Those who did not agree with the statement or question were numbered as 2 .

4. Those who had no comment or were not sure on a particular statement were numbered as 1 .

Various opinions given by the respondents were considered as their view about the particular concept and their stand. Frequency tables and crosstabulation techniques were carried out in analysing the opinions of the respondents. Frequency table was used to find the number of agreement and disagreement on certain research question and their answers were taken to support the issue in question (Cooper \& Schindler 2003). Crosstabulation technique was used to look for association (Davice, 2000).In this research article, this technique was useful to find out how many respondents from various industries and from different years of experience agreed or disagreed with a particular research question.

\section{Finding and Analysis}

The applicability of the principle of Donoghue v. Stevenson to e-manufacturers and service providers was asked in the survey conducted. The responses were as follows:

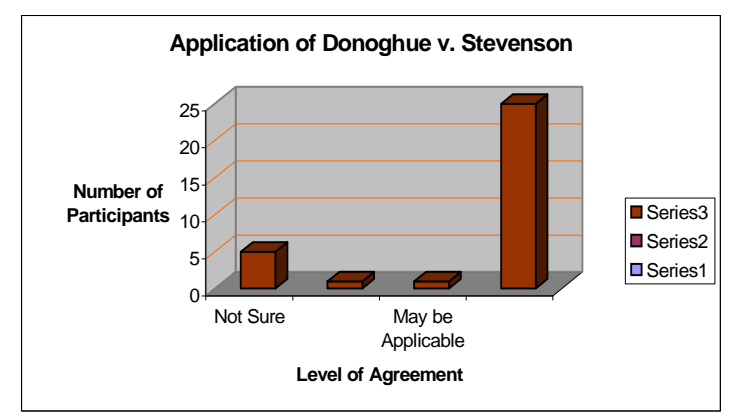

$78.1 \%$ (25) of the respondents felt that the principle applicable to them while $15.6 \%$ of them were not very sure of its application to emanufacturers and service providers. According to the majority, the manufacturers and service providers could be held liable in negligence if they failed in their duty, which causes any sort of loss.

1. They stated that they were in a better position to make sure that the products and services which were produced or rendered were as promised.

2. They also mentioned that if such liability was not available then they will be producing products and services without caring for their effectiveness.

3 . If the producers and service providers were liable offline they also should be liable online.
4. The principle of "neighbourhood" is general, thus it must be applied to e-manufactures and service providers too.

5. Since the e-consumers are the neighbours, they owe a duty.

Out of those who agreed that it was possible to extend the neighbourhood principle to emanufacturers and service providers, 16 of them had more than 10 years of experience, 7 of them had 6-10 years of experience and 2 persons had less than 6 years of experience.

Questions also addressed the issue of manufacturers' and service providers' liability. Even if there are possibilities of claiming compensation there are some constrains in full utilisation. This is due to the reason that compensation or succeeding in negligence against the service providers or professional advisors is only possible if the harm caused is only financial loss which is bound to happen in case of negligent statements. Under general law of negligence pure economic loss will not be compensated. Economic loss is either loss of profit or the reduction in value of an item of property . Nonetheless, in certain exceptional cases, the court may allow the plaintiff to recover economic loss provided that the defendant knew that the recipient would rely on the negligent statement that he made and the reliance was detrimental to the plaintiff.

The interviewees had stated that the economic loss should be considered as a sort of injury in all cases but not in exceptional cases. $56.3 \%$ of them felt that it is important in the case of ecommerce because economic loss is bound to happen often. One of the respondents pointed out that this issue can be offset by the legislation rather than by leaving it to the regulation of negligence tort. However, $21.9 \%$ of them had no stand in this matter. Majority of the academicians, all of the lawyers and legal advisors of consumer organisation had concurrent view on this issue despite some academicians and other interviewees representing other industries had dissenting opinion.

To succeed in an action against negligence it is necessary to establish a link between the breach of duty and the injury suffered which is another important issue that needs to be proven by the consumers. This linkage is called as "proximate cause" or "reasonable foreseeability." The causation and foreseeability are linked. No action in negligence will succeed if the plaintiff failed to prove that the defendant is the sole cause of damage. However, establishing causation in highly technical and medical matters is going to be very difficult as the claimant is not equipped with necessary 
knowledge of those technical issues. The diagram below explains the stand of interviewees in this regard.

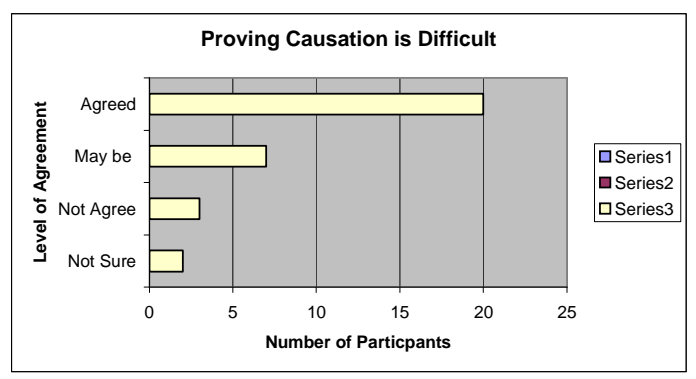

The interviewees also agreed with this fact. 19 of the respondents, in which 18 of them having more than 6 years of work experience said that proving causation in most of the cases involving technical matters, would be difficult. They argued that:

1. it was impossible for the consumers to have knowledge of their process, distribution, etc.,

2. consumers were only having limited knowledge as such it was better to introduce strict liability, and it required knowledge of their process, circumstances of product and services made.

The case of Bonington Castings Ltd v. Wardlaw 1956, that considered the difficulties in proving causation and foreseeability suggests that causation is considered proven in complex and technical cases if the product or services had materially contributed to the plaintiff's damage even if the defect was not the sole cause of injury.

In the case of chains of distribution and assembled products of various manufacturers, if the defect of one component part caused the damage that particular manufacturer can be held liable. If the consumer of the product causes his own injury by using the product in a manner which never have been intended or failed to follow the proper instructions or failed to exercise his duty of care, he may not be able to recover any damages under negligence.

In order to discharge the burden of proof, the plaintiff must prove that the damage is due to the manufacturer's or service provider's failure in their duty to take reasonable care. To establish the fault, the plaintiff must fully be informed of the defendant's process, circumstances of design made, tested and distributed. In Evans v. Triplex Safety Glass Co.Ltd, 1936, the plaintiff was anticipated to prove that the injury was due to manufacturer's fault. In proving this he has to eliminate every other possible cause of injury. In the case of
Grant v. Australian Knitting Mills Ltd.,1936, the court stated that:

"the plaintiff is not required to lay his finger on the exact person in all the chain who was responsible, or to specify what he did was wrong. Negligence is found as matter of inference from the existence of the defects taken in connection with all the known circumstances"

On the issue of the liability of Internet Service providers it should be noted that the liabilities of an ISP for content prepared and for communication sent by others will arise from the services which the ISP provides for its customers. Generally, the ISPs are being sued for the wrong or damage done by others because it is hard to sue someone whose whereabouts is unreachable. The clients who post infringing materials may be mobile or otherwise, are difficult to track down. Therefore, the victims have the tendency of initiating legal action against the ISPs as many ISPs are corporate entities with fixed places of business. In addition, the third party who posted the infringing or negligent materials online may be lacking financial resources to pay a substantial liability judgement. Therefore, the attention is shifted from the individual clients who had wronged to ISPs who have financial capacity to bear financial liabilities as they are well qualified as deep pockets.

In case of release of computer viruses like Melissa, ILOVEYOU, the question is can the ISP be held liable for the damage caused by the viruses as it had facilitated the communication of viruses? To date, it seems that applying negligence tort to virus caused damage has been difficult because it is not clear who should be held liable for the damage. Proving causation is also very difficult. In addition, the damage caused by the viruses is huge. For instance, the ILOVEYOU virus had caused damage worth $\$ 10$ billion around globe. Similarly in August 7, 1996 there was an online crash at American Online (AOL). In deciding the negligent liability the court would need to look at the question of who is most capable of taking effective precautions to prevent the attacks. The persons who are most capable of taking effective precautions are most likely those on whom the courts will impose liability if they do not take such precaution. In the event that the ISP is going to be held liable for such an extensive liability they will go bankrupt (Miller \& Vent, 2002). Therefore, there is a high chance that the court for policy consideration may exempt the liability from the purview of negligent liability and the victimised consumers may not be able to recover any loss caused. The outcome of the interview also 
supports this conclusion. $68.8 \%$ of them felt that it was very difficult to claim any compensation from anybody, be it the developer of software, hardware or Internet service providers. The reason being was that controlling the attack of new viruses was beyond the control of these people. One of them stated that it was difficult to claim from anyone. This is because the damage that was claimed was too remote. Another respondent felt that some sort of warranty must be imposed on the developers or service providers against new viruses. However, he added that this would be burdensome on the developers and service providers as the virus creators are ahead of software programmers.

However, there is a possibility that the ISP as publisher of negligent statement may be held responsible if a reader of its publication is seriously injured, died or suffered damage to his personal property after acting upon or using the content contained in the materials posted in its server. The publisher of Soldier of Fortune magazine was held liable for the death caused by a "hit man" following the magazine's publication of an advertisement for a professional mercenary, styled as a "gun for hire" (Rich, 2006). The publisher ISP is duty bound to provide adequate instructions, advice or warning if the publication contains inherently danger, and the reader by using or acting upon the information got injured or harmed or died.

However, the ISP can escape liability if it is proven that the ISP had an editor experienced in dealing with negligent publication conducted an independent review of the contents of the publication or included adequate warning to the reader with regard to the content of the publication. The warning must advise the reader that his or her failure to follow instruction is dangerous or includes potential risks(Rich, 2006). They may show that the warning given is specific and it was placed in the margin or apparent places of that section with an appropriate symbol to make the reader aware that this section contains information that could cause serious injury or death.

Proving negligence on the part of the ISP in allowing its services to be used for posting negligent statement or for facilitating the communication of viruses may be difficult. In the case of Alexander Lunney v. Prodigy Communications Corp, the US Supreme Court dismissed the suit against the ISP after an impostor using a 15-year-old boy's name sent threatening, profane and posted vulgar bulletin messages. In dismissing the action the Supreme Court upheld the decision of the New York Court of Appeal which stated that the Prodigy was not negligent in failing to prevent the impostor from opening the account using Lunney's name (Reuters, 2000).

The Malaysian e-consumer may not be able to bring an action against the Internet service providers under any of the existing law. This is because the Communication and Multimedia Act 1998, law regulating the ISP, in sections 211 and 233 states that the ISPs who knowingly enable or allow obscene, indecent or false menacing to harass another person, to be uploaded will be held liable. The provisions do not cover the liability of ISPs in negligence. Therefore, the consumers will only be able to bring an action under common law principle of negligence if they want to recover any damage done by the users of ISPs. In the event of bringing such an action, whether they will be able to succeed is an important question.

Negligence tort has provided an avenue for the e-consumers to bring an action against a manufacturer or service provider for damage suffered by him due to his defective products or design or services or wrongful advice. However, there are a number of problems in making full use of this remedy. The very basic problem of negligence tort is due to complex in procedural and evidential issues (Rachagan,1992).Without knowledge of industry practice and technology, it will be difficult to prove exactly which particular Act or omission owed caused injury. The negligence tort only benefits the econsumers when there is physical or property injury or death. It does not cover emotional injury. Even financial loss is covered only in limited cases. The major problem on this tort in benefiting the e-consumers is that the consumer alleging negligence needs to show fault of the defendant. Proving fault in the electronic environment on a specific defendant is extremely difficult as there are a number of parties ranging from manufacturer, service provider, ISP, portal site operators, search engines to Intranet operator are involved. In the event that if fault is proven, still he will not be able to recover any damages if the defendant is insolvent. Therefore, not only finding fault but also a solvent defendant is important to get some compensation for the damage or injury done to the innocent e-consumer. Failure of finding an insolvent defendant will deprive the plaintiff from getting any compensation.

On this point, the survey respondents showed the following trend:

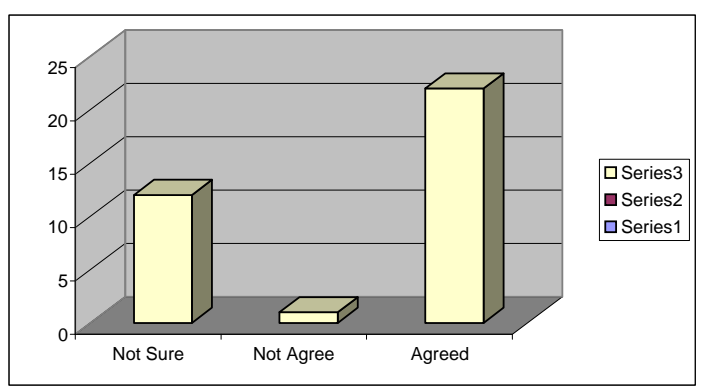


$59.4 \%$ agreed that succeeding in a case of negligence depends on finding fault on the part of the defendant. $37.5 \%$ of the respondents were not sure while $3.1 \%$ said that it was not necessary i.e. getting any compensation was not dependent on the fault and solvent defendant. The respondents stated that finding fault was not that very easy. Even if a case happened to be proven finding a solvent defendant was always going to be an issue. Therefore they observed that this area required serious consideration from the legislators.

\section{Conclusion}

Law of negligence in Malaysia has undergone very little development. There are calls for amendment to allow Malaysian law to progress with the development. The position of the econsumers in Malaysia seems not satisfactory on the account of the fact that any contract term or notice purporting to exclude or restrict liability for the death and personal injury resulting from negligence may be effective and enforceable. Generally, in determining the existence of a duty of care, the court in Malaysia applied the concept of reasonable foreseeability of harm established. In certain circumstances the court applied public policy in deciding whether the duty of care should be imposed. In the case of Mahmoon v. Government of Malaysia, 1974, applying public policy it was held that the police officer had not been negligent in firing the shots to effect the plaintiff's arrest. Applying public policy consideration would be better as it can protect the consumer well since Malaysia is promoting to become an e-commerce hub. However, it is not clear whether the courts will apply this consideration in making decisions on consumer claims.

In England, law of negligence has been very much developed, especially with regard to the extension and restriction of the concept of duty of care (Hedley Byrne \& Co. v. Heller \& Partner Ltd, 1964). There is no definite judicial response to these developments in Malaysia. In UK, the courts in determining the standard of care had considered the risk of harm. That is to say the greater the risk of harm, the higher the standard of care is required from the defendants. The court in analysing the risk considered in the context of gravity, frequency, imminence and foreseeability. There is no decision locally available to show whether these will be considered by Malaysian courts in determining duty of care. However, it is shown that the state of knowledge at the time of the occurrence is relevant in determining whether a particular harm is within the ambit of foreseeability (Elizabeth Choo v. Government of Malaysia,1970). Further, burden of proof is a major hurdle for persons seeking remedy in negligence. However, the application of law of negligence tort to protect e-consumers would be still restricted since proving all elements is not easy especially in the case of e-commerce. There are a number of parties involved in providing goods or services to the e-consumers. Determining who the person who owes duty is or who in fact breached the duty and a causal link between the injury and the breach of duty by the defendant that eventually caused the injury are the most difficult tasks on the plaintiff. In the case of e-commerce activities, economic loss by the software, expert systems and computer viruses is common and the loss caused is great. Therefore, the victim of economic loss will be recovering nothing. In addition, the procedural delay and the insufficient compensation have created doubt as to the effective protection of e-consumers against negligence tort.

\section{References}

[1] Grant v. Australian Knitting Mills Ltd. Appeal Cases, 1936, p.85.

[2] Evans v. Triplex Safety Glass Co.Ltd., All England Report, 1936 p.283.

[3] Bonington Castings Ltd. v. Wardlaw, Appeal Cases, 1956, p. 613.

[4] Burgunder, B.L. Legal Aspects of Managing Technology, (2nd Ed.) Thomson Learning, Ohio, 2001.

[5] Cooper, Donald, C, \& Schindler, Pamela, S. Business Research Method, McGraw Hill, USA 2003.

[6] Davice, Duane. Business Research for Decision Making. (5th ed), Thomson learning, Pacific Grove, 2000.

[7] Diane W. Savage. The impact of Proposed Article 2B of the Uniform Commercial Code on Consumer Contracts for Information and Computer Software, Retrieved December 72008 , http://library.lp.findlaw.com/scripts/getfile.pl?f ile+/forms/cg/cg000011.html.

[8] Donoghue v. Stevenson, Appeal Cases 1932, p.562.

[9] Keenan, D. Smith \& Keenan Advanced Business Law, Longman, England, 2000.

[10] Keenan, D, and Riches Sarah. Business Law, Pitman Publishing, London, 1998.

[11] Malhotra, Naresh, et.al. Marketing Research: An applied Orientation. (2nd ed.), Prentice Hall, Australia, 2002. 
[12] Miller, L. R, \& Jentz, A.G. Law for ECommerce, Thomson Learning, USA, 2002.

[13] Rachagan, S.S. Consumer Law Reform- A Report, Selangor and Federal Territory Consumers' Association, Malaysia, 1992.

[14] Reuters. Supreme Court upholds ISP Ruling, Retrieved December 8, 2008, http://www.wired.com/news/politics/0,1283,3 6012,00.html.

[15] Rich, L.L. Publisher Liability: Incitement \& Negligent Publication, Retrieved December 8, 2008,

http://library.lp.findlaw.com/articles/file/0010 $2 / 000149 /$ title/subject/topic/injury\%20\%20to rt\%20law_defamation/libel/slander/filename/i njurytortlaw_1_213

[16] Sathu v. Hawthorrden Rubber Estate co. Ltd, Malayan Law Journal, 1961, p.318.
[17] Scott, C. \& Black, J. Cranston's Consumers and The Law. (3rd ed.), Butterworths, London, 2000.

[18] Stephenson, P. et.al. (2001). Cyberlaw in Hong Kong, Butterworths, Hong Kong, 2001.

[19] Uma Sekaran. Research Methods for Business: A Skill Building Approach, John Wiley \& Sons, USA, 2003.

[20] Vos, Geoffrey. (2001). Linking Chains of Causation: An Examination of New Approaches to Causation in Equity and the Common Law. Cambridge Law Journal (60:2) 2001, pp. 342387.

[21] Whincup, M., Sales Law and Product Liability: A Business Guide, McGraw Hill, USA, 1999. 